\title{
ENVIRONMENTAL PRACTICE AND ITS EFFECT ON THE SUSTAINABLE DEVELOPMENT OF ECO-INDUSTRIAL PARKS IN CHINA
}

\author{
Y. QU, M. LI \& L. QIN \\ Faculty of Management and Economics, Dalian University of Technology, China.
}

\begin{abstract}
After more than a decade of development, eco-industrial parks (EIPs) have made significant progress in saving resources and protecting the environment in China. Meanwhile, many problems have emerged, such as poor stability, poor profitability and weak eco-industrial chains, which have impeded the EIP's sustainable development. Faced with variable environmental practices and limited resources and capital, EIPs need to address suitable environmental practices seriously to configure resources reasonably and ultimately realize sustainable development. Therefore, based on an analysis of the elements of environmental practice and sustainable development level, this article aims at identifying those environmental practices that can improve the sustainable development level of EIPs and to analyze the impact of those different environmental practices on the sustainable development level of EIPs using factor analysis and analytic hierarchy process. The results could provide theoretical guidance and reference for decision-making to Chinese government and administration committees of EIPs for choosing and implementing environmental practices.

Keywords: eco-industrial parks (EIPs), environmental practice, the sustainable development level.
\end{abstract}

\section{INTRODUCTION}

Eco-industrial parks (EIPs) are the third-generation industrial parks, following the economic and technological development zone and high-tech park. An EIP is an important practical means of implementing sustainable development [1,2]. EIPs maximize resource utilization and minimize waste emission by converting linear production processes into closed-loop processes that divert upstream waste outputs to the raw material inputs needed by downstream producers; therefore, EIPs both reduce the burden on environmental resources and produce economic benefits, a double efficiency, which is their core principle [3].

Since the early 1990s, developed countries, such as the United States and Canada, began to promote EIP projects. By the late 20th century, more than 20 EIPs had been established in developed countries [4] and had achieved remarkable results in resource conservation, waste recycling, energy cascade utilization and water recycling and other practices. Economic and social benefits have followed from the effective protection of the ecological environment as well [5]. In 1999, China began to construct an Eco-Industrial Park Demonstration Garden, and by September 2008, 27 National Eco-Industrial Park Demonstration Gardens had been approved by Chinese government [6]. Through industrial symbiosis, by-product exchange and other processes, representative EIPs, such as Tianjin Economic Technological Development Zone and Guigang National Eco-industrial Demonstration Park, have been built and have already achieved a high level of the sustainable development.

In fact, Chinese Government provides great importance to the implementation of environmental practices during the construction of EIPs, such as making relatively comprehensive policies and regulations, and providing money and technical support. However, with the continuous development of EIPs, many problems have emerged, such as poor stability, poor profitability, policy objectives dislocation and weak eco-industrial chains. Specifically, poor stability, defined as 'vulnerability in the composition, structure and function of EIP', impairs EIPs' product exchange [7]; poor profitability implies that EIPs have no enough capitals to update equipment, introduce new 
technology, raise management level and so on [8]; policy objectives dislocation refers to the EIPs' actual functions disjointed with the initial design target, which illustrates the EIP design is failing [8]; weak eco-industrial chains mean that the ecological industry chains of EIPs is not closed-loop, lacking exchange of by-products or waste, which weakens the environmental sustainable development of EIPs [1]. These problems have seriously impeded the sustainable development of EIPs. Facing changing environmental practices and limited resources and capitals, EIPs need to choose environmental practices to configure resources reasonably and ultimately realize sustainable development. Therefore, based on an analysis of the elements of environmental practices and sustainable development level, this article aims at identifying those environmental practices that will help EIPs improve their sustainable development level and to analyze the influence of those different environmental practices on the sustainable development level using factor analysis and analytic hierarchy process. The results will provide theoretical guidance and reference for decision-making to Chinese Government and administration committees of EIPs in choosing and implementing environmental practices.

This article proceeds as follows: Section 2 is the literature review. Section 3 begins with the development of a questionnaire followed by the samples. Section 4 describes the methodology and data analysis in detail. Section 5 presents the results. The conclusions are presented in Section 6.

\section{LITERATURE REVIEW}

\subsection{Sustainable industrial development}

The idea of sustainable development is first put forward in 1972. Since then, more than 100 kinds of the definition of sustainable development were proposed. But the most widely accepted and the most influential definition was put forward by United Nations World Commission on Environment and Development (WCED) in 1987 in 'our common future'. Sustainable development is defined as 'meet the needs of the present without compromising the ability of future generations to meet their own needs' [9]. In 2002, the World Summit on Sustainable Development argued that sustainable development includes three aspects, which are social, environmental and economic sustainable development [10]. The United Nations Secretary's 2012 report emphasized that sustainable development offers chance for people to make production and consumption more sustainable and growth inclusive [11]. Lorek and Spangenberg [12] characterized sustainable development as 'living within the ecological limits and meeting the needs of everyone'.

Based on the concept of sustainable development, researchers conducted many studies about the industrial areas' sustainable development that is industrial sustainable development. To improve the sustainable development capacity of industry, government, enterprises and other stakeholders should take up some measures, such as implementing sustainable production and building industrial ecology and green industry [13,14]. The application of the concept of sustainable development drives industrial sector to a new industrialization road, whose characteristics are cleaner production, green technology, high-tech manufacture and remanufacture and less resources consumption and environmental pollution $[15,16]$. And in socio-economic development, lower inputs, higher efficiency and lower emissions are the characteristics of sustainable industrial development [17,18]. As a result, Nguyen and Ye [19] argued that 'sustainable industrial development is a new model of economic development that can achieve sustainable development and resolve the conflict between socioeconomic development and environmental protection'. 


\subsection{Environmental practices in EIPs}

Since the concept of EIP was proposed, a lot of researches on EIP have been conducted by academicians and practitioners. These studies mainly focused on industrial ecology theory (the theoretical basis of EIP) [20-22], industrial symbiosis (a core component of EIP) [23-25], EIP design [26,27] and EIP as regional development strategy [28,29]. Except these theory and strategy studies, there are some studies exploring the environmental practices of EIPs, which is the focus of this literature review.

From a personal perspective, environmental practice, also known as environmental behavior, includes actions such as responsible consumerism (e.g. choosing products that are recycled or environmental-friendly), resource conservation (e.g. reusing, energy conservation), use of nature (e.g. being outdoors), antitoxic (e.g. avoid use of toxic products in the garden/yard) and waste handling (e.g. recycling, composting, reduced littering) [30]. From an organizational perspective, environmental practice points to measures and actions (e.g. setting strict environmental standards, implementation of cleaner production, introducing green technology, improving managers' environmental awareness, increasing investment in environmental protection and pollution control) adopted by an organization according to their own characteristics and development strategy in the face of pressure from the government, the public and other stakeholders for environmental protection [31]. At present, EIPs' environmental practices have no uniform definition and division, and existing researches on the environmental practices of EIPs mainly focus on the four aspects, execution of environmental norms, construction of industrial symbiosis, popularity of eco-industrial knowledge and guidance to key enterprises.

Execution of environmental norms needs mutual efforts from stakeholders, especially EIP enterprise managers. The establishment, planning and operation of EIPs require enterprise managers to strictly implement environmental norms, such as energy conservation system, energy reduction system, waste recycling system and environmental information disclosure system, green technology support systems, including technologies for eliminating pollution, recycling waste and cleaner production, and other environmental-related systems, and gain the ISO14001 environmental management system certification and other environmental-related certification to reduce pollution emission and improve energy use efficiency [32-38].

Construction of industrial symbiosis is an important part for EIPs' implementation of industrial ecology and sustainable development. To build industrial symbiosis, EIPs should combine with related enterprises ecologically. For example, by means of cleaner production, waste exchange and recycling, the waste produced by an enterprise can become the raw material for another enterprise. Gradually, a closed-loop structure can be formed to minimize waste discharge and ultimately achieve pollution zero-emission. Some initiatives, such as by-product exchange, water and waste recycling, energy cascading, resource and information sharing, construction of eco-industrial networks and cooperation with stakeholders (suppliers, government agencies, communities, customers, etc.), are beneficial to build industrial symbiosis successfully [39-41].

Popularity of eco-industrial knowledge is very important to perfect EIPs' sustainable development. Some studies expressed that actions should be taken to enhance EIPs relevant personnel environmental awareness and knowledge to improve EIPs' ecological environment [42,43]. Deng [44] found that in an EIP, if enterprise leaders and members have a better understanding of ecology, the stability of EIPs will be improved.

Key enterprises' support for environmental sustainability principles and values is of importance to improve EIPs' sustainable development. Deng [44] stated that key enterprises can be helpful to build 
EIPs' cohesiveness and stability, which is due to the environmental behaviors of key enterprises that have an positive influence on EIPs' other smaller enterprises. What's more, key enterprises usually have considerable effect in their EIPs because of their outstanding and central roles; they tend to stimulate EIPs' other enterprises to carry out environmental practices when they become pioneers and obtain experience, knowledge, economic benefit and social satisfaction from implementing environmental practices [45]. Thus, key enterprises in EIPs are guided to carry out environmental practices through making environmental protection-related policies and regulations and advocating the application of environmental management tools.

\section{QUESTIONNAIRE DEVELOPMENT AND SAMPLES}

\subsection{Questionnaire development}

Based on literature review and interviews with managers in Chinese EIP Administration Committees, this study developed 21 questions about environmental practices; these questions mainly focused on execution of environmental norms, construction of industrial symbiosis, popularity of eco-industrial knowledge and guidance of key species enterprises, which are shown in Table 1.

Sustainable development includes social, environmental and economic sustainable development [10]. Sustainable development of EIPs is based on applying sustainable development theory to the development of EIP; specifically, a park's development needs to achieve the common, sustainable and equitable development of critical systems, including the economy, resources and environment. Specifically, during the construction process of the park, the development process needs to maintain the harmonious and stable development of the economy, environment and society to reduce resource consumption and pollutants emissions and to achieve a balance between people and nature. Based

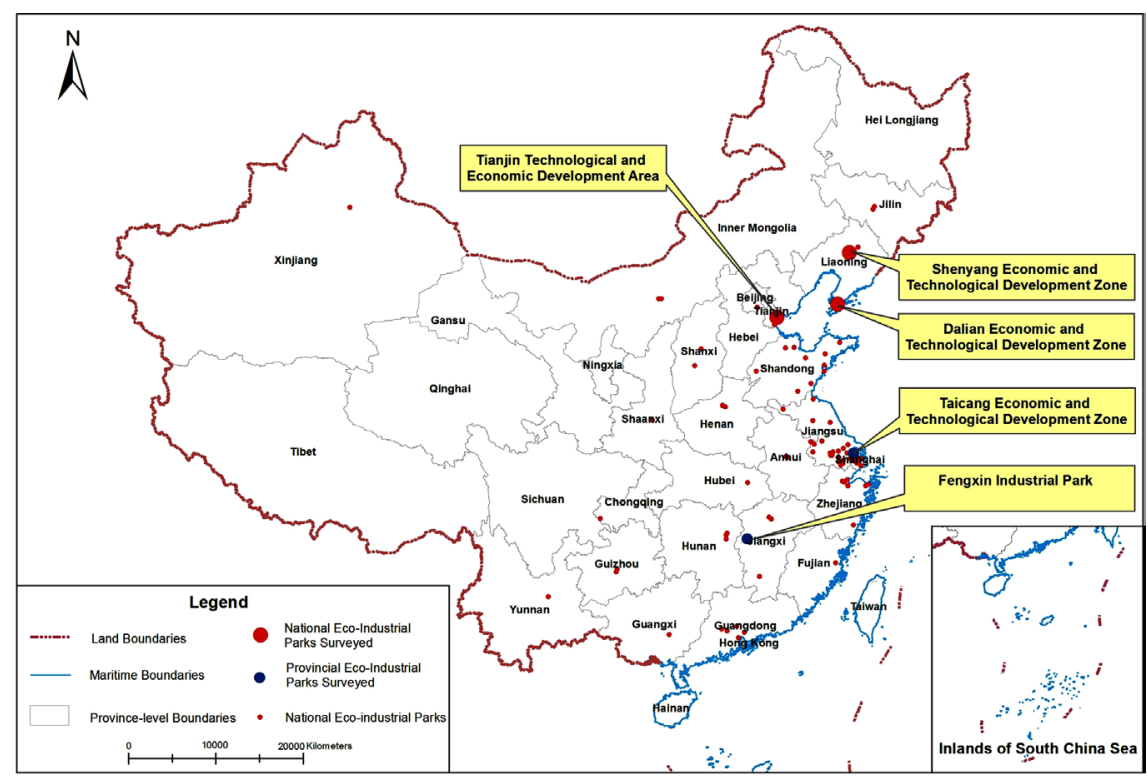

Figure 1: The geographical distribution of the national EIPs in China. 
on the construction of EIPs and the sustainable development concept, 18 questions from the perspectives of economy, environment and society were selected, which are shown in Table 2.

\subsection{Samples}

The questionnaire is designed for EIPs' environmental practice and EIPs' sustainable development level. With the support of the National Natural Science Foundation of China, five national and provincial EIPs located in the eastern and central areas were selected to participate in the questionnaire survey; they are Tianjin Technological and Economic Development Area, Taicang Economic and Technological Development Zone, Fengxin Industrial Park, Dalian Economic and Technological Development Zone and Shenyang Economic and Technological Development Zone, which are shown in Fig. 1. Questionnaires were given to those EIPs' administration committees and the Economic and Information Technology Bureau, Development and Reform Bureau and Human Resources Social Security Bureau. The questionnaires were distributed from March to November 2011. A total of 308 questionnaires were distributed, 276 were received and 248 were valid, with the effective rate of $75.6 \%$. The number of valid questionnaires meets the recommendation [46] that for the survey to be effective; the number of valid surveys should be at least five times the number of questions asked on the questionnaire.

\section{METHODOLOGY AND DATA ANALYSIS}

\subsection{Methodology}

In this article, factor analysis, one of the statistical analysis methods, was applied to deal with the data. Factor analysis is a statistical technique that extracts common factors from variable groups. It is an effective method to group those items containing more similar information into one variable so as to simplify analysis procedure by reducing the number of variables [47]. The main procedures of factor analysis are as follows. The first step is to judge whether variables are suitable for factor analysis or not. The criterion is KMO (Kaiser-Meyer-Olkin) value. When KMO value is above 0.8, the variables are suitable for factor analysis [48]. Second, according to the criteria of eigenvalue $>1$ and cumulative variance contribution rate more than $70 \%$ the main factors are extracted and the number of main factors is determined [49]. The third step is to conduct a reliability analysis to test the reliability of each main factor. The criterion is that Cronbach's $\alpha$ exceeds 0.70 [49].

\subsection{Analysis of structural elements}

4.2.1 Structural elements of EIP's environmental practice

To classify similar questions into groups, factor analysis was conducted for all 21 questions about environmental practices. The KMO (a statistic to judge whether variables are suitable for factor analysis or not) value is 0.967 ( $>0.8)$, which means that the variable is very suitable for factor analysis [50]. Considering factors with eigenvalues $>1$ and the cumulative variance contribution rate of the four main factors was $82.161 \%(>70 \%)$, the four main factors were extracted. Considering the meanings of the questions that were grouped into each main factor, the four main factors were named construction of industrial symbiosis, execution of environmental norms, guidance to key enterprises and popularity of eco-industrial knowledge, in decreasing order of their contribution. To further test the reliability of each main factor, a reliability analysis was conducted. The Cronbach $\alpha$ (a statistic to measure reliability) values are 0.922, 0.950, 0.964 and 
Table 1: Factor analysis for environmental practices.

\begin{tabular}{|c|c|c|c|c|c|c|c|}
\hline \multirow[t]{2}{*}{ Variables } & \multirow[t]{2}{*}{ Questions } & \multicolumn{4}{|c|}{ Factor } & \multirow[t]{2}{*}{$\begin{array}{l}\text { Contribution } \\
\text { rate }\end{array}$} & \multirow[t]{2}{*}{ KMO } \\
\hline & & 1 & 2 & 3 & 4 & & \\
\hline \multirow[t]{8}{*}{$\begin{array}{l}\text { Construction } \\
\text { of industrial } \\
\text { symbiosis }\end{array}$} & $\begin{array}{l}\text { Park build the network } \\
\text { platform which can help } \\
\text { enterprises to exchange by- } \\
\text { products and waste }\end{array}$ & 0.606 & 0.353 & 0.434 & 0.161 & \multirow{12}{*}{$30.358 \%$} & \multirow{12}{*}{0.967} \\
\hline & $\begin{array}{l}\text { Park supports the diversity of } \\
\text { ecological industry chain }\end{array}$ & 0.685 & 0.396 & 0.312 & 0.213 & & \\
\hline & $\begin{array}{r}\text { Water recycling between } \\
\text { enterprises in the park }\end{array}$ & 0.777 & 0.251 & 0.299 & 0.270 & & \\
\hline & $\begin{array}{l}\text { Energy cascade utilization } \\
\text { between enterprises in the } \\
\text { park }\end{array}$ & 0.806 & 0.283 & 0.249 & 0.244 & & \\
\hline & $\begin{array}{l}\text { By- product exchange between } \\
\text { enterprises in the park }\end{array}$ & 0.793 & 0.198 & 0.299 & 0.216 & & \\
\hline & $\begin{array}{l}\text { Information sharing between } \\
\text { enterprises in the park }\end{array}$ & 0.788 & 0.283 & 0.232 & 0.306 & & \\
\hline & $\begin{array}{l}\text { Environmental cooperation be- } \\
\text { tween the park enterprises } \\
\text { and outside vendors }\end{array}$ & 0.769 & 0.305 & 0.261 & 0.339 & & \\
\hline & $\begin{array}{c}\text { Environmental cooperation } \\
\text { between park enterprises } \\
\text { and external customers }\end{array}$ & 0.751 & 0.276 & 0.276 & 0.400 & & \\
\hline \multirow[t]{4}{*}{$\begin{array}{l}\text { Guidance to } \\
\text { key } \\
\text { enterprises }\end{array}$} & $\begin{array}{l}\text { Park guides the keystone en- } \\
\text { terprise to develop cleaner } \\
\text { production }\end{array}$ & 0.316 & 0.666 & 0.373 & 0.260 & & \\
\hline & $\begin{array}{l}\text { Park encourages the key- } \\
\text { stone enterprises to obtain } \\
\text { ISO14001 certification }\end{array}$ & 0.317 & 0.684 & 0.409 & 0.329 & & \\
\hline & $\begin{array}{l}\text { Park promotes the keystone } \\
\text { enterprises to develop and } \\
\text { use renewable or clean } \\
\text { energy resources }\end{array}$ & 0.305 & 0.656 & 0.400 & 0.340 & & \\
\hline & $\begin{array}{l}\text { Park encourages the keystone } \\
\text { enterprises to improve en- } \\
\text { ergy efficiency and develop } \\
\text { energy conservation }\end{array}$ & 0.381 & 0.694 & 0.321 & 0.376 & & \\
\hline
\end{tabular}


Table 1: Continued

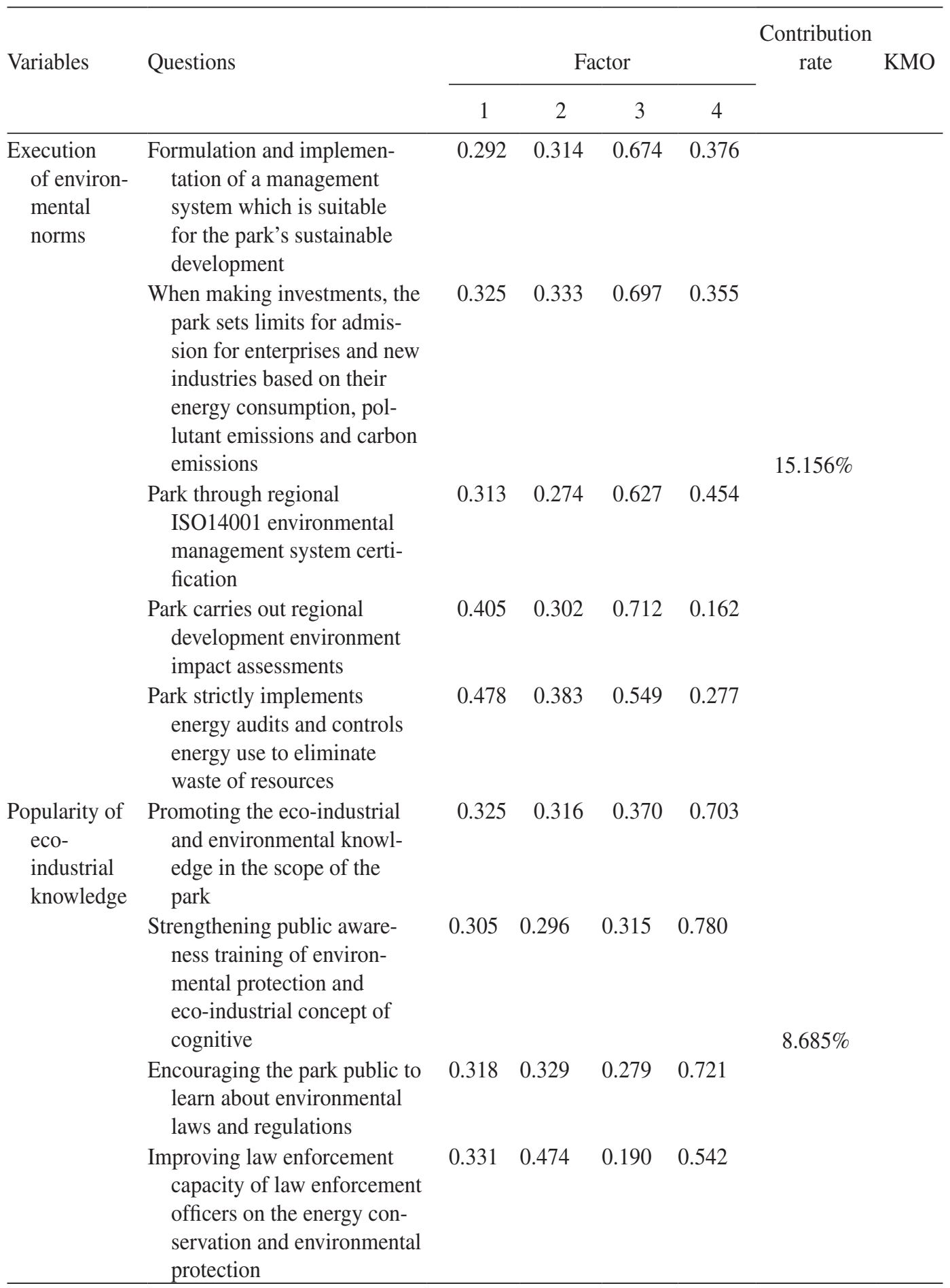

Note: Convergence in seven iterations. 
0.932; all of them exceed 0.70 , which is the benchmark of reliability. Removing any one item will not significantly increase any of the four Cronbach $\alpha$ values, and in some cases, the Cronbach $\alpha$ value is reduced. Therefore, all of the questions in each main factor need to be retained [51]. According to the meaning of contribution rate in factor analysis and the main factors' contribution rate, it is reasonable to assume that the construction of industrial symbiosis factor contributes $30.358 \%$ of $82.161 \%$ to the environmental practices. Similarly, guidance to key enterprises contributes $27.962 \%$, execution of environmental norms contributes $15.156 \%$ and popularity of eco-industrial knowledge contributes $8.685 \%$. Table 1 shows the results of the factor analysis for environmental practices.

4.2.2 Structural elements of EIP's sustainable development level

Similarly, factor analysis was conducted to group the 18 questions of sustainable development levels. The factor analysis results (shown in Table 2) indicate that three main factors can be identified that have eigenvalues greater than 1 . According to the meanings of the questions in each main factor, these main factors were named economic level, environmental level and social level. It is reasonable to assume that economic level contributes $33 \%$ of $75.5 \%$ to the EIP's sustainable development level. Similarly, environmental level contributes $21.5 \%$ and social level contributes $21 \%$.

Following the analytic hierarchy process, EIP's sustainable development level (Level 1 indicator, y) can be subdivided into three sublevels: economic, environmental and social (Level 2 indicators, $y_{1}, y_{2}$ and $y_{3}$ ). The four main factors of environmental practices can be represented as Level 3 indicators $\left(x_{1}, x_{2}, x_{3}\right.$ and $\left.x_{4}\right)$. The questions of environmental practices can be represented as Level 4 indicators $\left(x_{i j}, i=1-4, j=1-8\right)$.

To calculate the impact of environmental practices on the sustainable development level of an EIP, the contribution of the economic, environmental and social level to the sustainable development level of an EIP first needs to be determined. Second, the impact of the four environmental practice factors on the three factors of sustainable development level needs to be determined.

To address the first question, the contribution rate of each level was used to calculate their weights.

The weights $c_{i}$ were obtained by normalizing the main factor contribution rates $a_{i}$ :

$$
c_{i}=a_{i} /\left(a_{1}+a_{2}+a_{3}\right)
$$

In this equation, $\mathrm{a}_{\mathrm{i}}$ is the contribution rate of main factor $i$ and $c_{i}$ is the weight of main factor $i$.

Using factor analysis, the contribution rates of three main factors are $33.044 \%, 21.516 \%$ and $20.956 \%$, and the cumulative contribution rate is $75.516 \%$. Therefore, from eqn (1), the contributions of the economic, environmental and social level to the sustainable development level are $c_{1}=$ $0.428, c_{2}=0.285$, and $c_{3}=0.277$, respectively.

The relationship between sustainable development level and economic, environmental and social levels can be expressed as:

$$
y=0.428 y_{1}+0.285 y_{2}+0.277 y_{3}
$$

4.3 The regression analysis between environmental practice and sustainable development level

A regression analysis was used to determine the contributions of the four factors of environmental practices on the three levels of sustainable development. The four factors of environmental practices were taken as independent variables, and the three factors of sustainable development, economic level, environmental level and social level were taken as dependent variables. The results are shown in Table 3. 
Table 2: Factor analysis for sustainable development level.

\begin{tabular}{|c|c|c|c|c|c|c|}
\hline \multirow[b]{2}{*}{ Variables } & \multirow[b]{2}{*}{ Questions } & \multicolumn{3}{|c|}{ Factor } & \multirow{2}{*}{$\begin{array}{l}\text { Contribution } \\
\text { rate } a_{i}\end{array}$} & \multirow[b]{2}{*}{$\mathrm{KMO}$} \\
\hline & & 1 & 2 & 3 & & \\
\hline \multirow[t]{9}{*}{$\begin{array}{l}\text { Economic } \\
\text { level }\end{array}$} & $\begin{array}{l}\text { The park position on the economic } \\
\text { scale of national industrial parks }\end{array}$ & 0.747 & 0.227 & 0.296 & \multirow{9}{*}{$33.044 \%$} & 0.945 \\
\hline & $\begin{array}{l}\text { The market position of the park's } \\
\text { leading industry }\end{array}$ & 0.726 & 0.220 & 0.351 & & \\
\hline & $\begin{array}{l}\text { The impact of market changes on } \\
\text { the overall development of the } \\
\text { park }\end{array}$ & 0.801 & 0.261 & 0.099 & & \\
\hline & $\begin{array}{l}\text { The impact of market changes on } \\
\text { the leading industries in the park }\end{array}$ & 0.829 & 0.282 & 0.169 & & \\
\hline & $\begin{array}{l}\text { The ability of the park to access } \\
\text { foreign investment channels }\end{array}$ & 0.769 & 0.257 & 0.319 & & \\
\hline & $\begin{array}{l}\text { Park development efforts of strategy } \\
\text { or policy }\end{array}$ & 0.781 & 0.223 & 0.280 & & \\
\hline & $\begin{array}{l}\text { The attractiveness of the park for a } \\
\text { growing business }\end{array}$ & 0.745 & 0.312 & 0.359 & & \\
\hline & $\begin{array}{l}\text { The investment efforts of improving } \\
\text { park existing industrial chain }\end{array}$ & 0.679 & 0.297 & 0.412 & & \\
\hline & $\begin{array}{l}\text { The park staff satisfaction with } \\
\text { wages }\end{array}$ & 0.542 & 0.407 & 0.434 & & \\
\hline \multirow[t]{4}{*}{$\begin{array}{l}\text { Environmental } \\
\quad \text { level }\end{array}$} & $\begin{array}{l}\text { The extent of saving water in the } \\
\text { park }\end{array}$ & 0.312 & 0.838 & 0.236 & \multirow{4}{*}{$21.516 \%$} & \\
\hline & $\begin{array}{l}\text { The extent of park energy recycling } \\
\text { and reducing }\end{array}$ & 0.345 & 0.832 & 0.230 & & \\
\hline & $\begin{array}{l}\text { The realized extent of by-product } \\
\text { exchange between enterprises in } \\
\text { the park }\end{array}$ & 0.260 & 0.818 & 0.304 & & \\
\hline & $\begin{array}{l}\text { The degree of park enterprise waste } \\
\text { reduction }\end{array}$ & 0.294 & 0.817 & 0.316 & & \\
\hline \multirow[t]{5}{*}{ Social level } & $\begin{array}{l}\text { The degree of public satisfaction of } \\
\text { the park's employment stability } \\
\text { and working conditions }\end{array}$ & 0.451 & 0.327 & 0.543 & \multirow{5}{*}{$21.965 \%$} & \\
\hline & $\begin{array}{l}\text { The degree of public satisfaction } \\
\text { with the park management }\end{array}$ & 0.454 & 0.362 & 0.593 & & \\
\hline & $\begin{array}{l}\text { Awareness of the public to the } \\
\text { concept of sustainable develop- } \\
\text { ment }\end{array}$ & 0.335 & 0.202 & 0.813 & & \\
\hline & $\begin{array}{l}\text { The degree of park management } \\
\text { emphasis on the concept of } \\
\text { sustainable development }\end{array}$ & 0.329 & 0.227 & 0.820 & & \\
\hline & $\begin{array}{l}\text { The park and the surrounding } \\
\text { public's environmental awareness }\end{array}$ & 0.149 & 0.311 & 0.759 & & \\
\hline
\end{tabular}

Note: Convergence in five iterations. 
Table 3: The results of regression analysis between environmental practices and the three levels of sustainable development.

\begin{tabular}{|c|c|c|c|c|c|c|c|}
\hline $\begin{array}{l}\text { Dependent } \\
\text { factor }\end{array}$ & Independent factor & $\begin{array}{c}\text { Standardized } \\
\text { coefficient }\end{array}$ & $t$ & Sig. & $\begin{array}{c}\text { Adjusted } \\
\mathrm{R}^{2}\end{array}$ & Tolerance & $\begin{array}{l}\text { Durbin- } \\
\text { Watson }\end{array}$ \\
\hline \multirow{5}{*}{$\begin{array}{l}\text { Economic } \\
\text { level, } y_{1}\end{array}$} & Constant & & 10.977 & 0.000 & \multirow{5}{*}{0.476} & & \multirow{5}{*}{1.821} \\
\hline & $\begin{array}{l}\text { Construction of } \\
\text { industrial } \\
\text { symbiosis, } x_{1}\end{array}$ & 0.010 & 0.108 & 0.914 & & 0.656 & \\
\hline & $\begin{array}{l}\text { Execution of } \\
\text { environmental } \\
\text { norms, } x_{2}\end{array}$ & 0.602 & 6.437 & 0.000 & & 0.660 & \\
\hline & $\begin{array}{l}\text { Guidance to key } \\
\text { enterprises, } x_{3}\end{array}$ & 0.524 & 6.021 & 0.002 & & 0.532 & \\
\hline & $\begin{array}{l}\text { Popularity of eco- } \\
\text { industrial } \\
\text { knowledge, } x_{4}\end{array}$ & 0.128 & 2.110 & 0.036 & & 0.615 & \\
\hline \multirow{5}{*}{$\begin{array}{l}\text { Environmental } \\
\text { level, } y_{2}\end{array}$} & Constant & & 5.445 & 0.000 & & & \multirow{5}{*}{1.986} \\
\hline & $\begin{array}{l}\text { Construction of } \\
\text { industrial } \\
\text { symbiosis, } x_{1}\end{array}$ & 0.609 & 4.793 & 0.006 & & 0.773 & \\
\hline & $\begin{array}{l}\text { Execution of } \\
\text { environmental } \\
\text { norms, } x_{2}\end{array}$ & 0.531 & 7.048 & 0.000 & 0.715 & 0.570 & \\
\hline & $\begin{array}{l}\text { Guidance of key } \\
\text { enterprises, } x_{3}\end{array}$ & 0.326 & 3.960 & 0.001 & & 0.720 & \\
\hline & $\begin{array}{l}\text { Guidance to key } \\
\text { enterprises, } x_{4}\end{array}$ & 0.191 & 3.821 & 0.000 & & 0.616 & \\
\hline \multirow{5}{*}{$\begin{array}{l}\text { Social } \\
\quad \text { level, } y_{3}\end{array}$} & Constant & & 6.079 & 0.000 & \multirow{5}{*}{0.632} & \multirow[b]{2}{*}{.637} & \multirow{5}{*}{1.903} \\
\hline & $\begin{array}{l}\text { Construction of } \\
\text { industrial } \\
\text { symbiosis, } x_{1}\end{array}$ & 0.101 & 1.222 & 0.003 & & & \\
\hline & $\begin{array}{l}\text { Execution of } \\
\text { environmental } \\
\text { norms, } x_{2}\end{array}$ & 0.607 & 7.361 & 0.000 & & 0.829 & \\
\hline & $\begin{array}{r}\text { Guidance to key } \\
\text { enterprises, } x_{3}\end{array}$ & 0.265 & 3.867 & 0.004 & & 0.530 & \\
\hline & $\begin{array}{l}\text { Popularity of eco- } \\
\text { industrial } \\
\text { knowledge, } x_{4}\end{array}$ & 0.153 & 2.994 & 0.003 & & 0.622 & \\
\hline
\end{tabular}


The impact of the four factors of environmental practices, $x_{1}, x_{2}, x_{3}$ and $x_{4}$, on economic level $y_{1}$ is represented by $b_{1 j}$, their impact on environmental level $y_{2}$ is represented by $b_{2 j}$ and their impact on social level $y_{3}$ is represented by $b_{3 j}(\mathrm{~J}=1,2,3,4)$. By normalizing the standardized coefficients in each regression analysis model, the values of $b_{i j}(\mathrm{i}=1,2$, and $3 \mathrm{j}=1,2,3$ and 4 ) can be determined. The relationship between the four factors of environmental practices and the three factors of sustainable development are described as follows:

$$
\begin{aligned}
& y_{1}=0.070 x_{1}+0.445 x_{2}+0.387 x_{3}+0.094 x_{4} \\
& y_{2}=0.368 x_{1}+0.320 x_{2}+0.197 x_{3}+0.115 x_{4} \\
& y_{3}=0.09 x_{1}+0.539 x_{2}+0.235 x_{3}+0.136 x_{4}
\end{aligned}
$$

According to the eqns (3)-(5), the construction of industrial symbiosis contributes $7 \%, 36.8 \%$ and $9 \%$ to the economic, environmental and social levels of sustainable development, respectively. Similarly, the execution of environmental norms contributes $44.5 \%, 32 \%$ and $53.9 \%$, respectively. Guidance to key enterprises contributes $38.7 \%, 19.7 \%$ and $23.5 \%$, respectively. Popularity of ecoindustrial knowledge contributes $9.4 \%, 11.5 \%$ and $13.6 \%$ to the three levels, respectively. It was also found that execution of environmental norms has the greatest impact on economic level and social level, and the construction of industrial symbiosis has the greatest impact on environmental level. Therefore, the contribution rates can be used to represent the weights of the Level 3 indicators (environmental practices) on the Level 2 indicators (the three levels of sustainable development).

4.4 The analysis of the impact of environmental practice on the sustainable development level

To calculate the effect of environmental practice (Level 3 indicators) on sustainable development (Level 1 indicator) in an EIP, the analytic hierarchy process was used to calculate the weights of Level 3 indicators on the Level 1 indicator. By using the weights $c_{i}$ (eqn (1) of the three Level 2 indicators(economic level, environmental level and social level on the sustainable development) and the impact $b_{i j}$ (impact of indicators Level 3 on indicators Level 2, as shown in eqns (3)-(5)), the weight $w_{j}$ of Level 3 indicators $\left(x_{j}\right)$ on the level indicator $1(y)$ can be calculated:

$$
w_{j}=\sum_{i=1}^{3} b_{i j} \times c_{i}
$$

According to eqn (6), the influence powers of the four factors of environmental practices on sustainable development level were calculated. The results of the calculations are as follows.

The impact of construction of industrial symbiosis on the sustainable development level is:

$$
w_{1}=0.07 * 0.428+0.368 * 0.285+0.09 * 0.277=0.17
$$

The impact of execution of environmental norms on the sustainable development level is:

$$
w_{2}=0.445 * 0.428+0.320 * 0.285+0.539 * 0.277=0.43
$$

The impact of guidance to key enterprises on the sustainable development level is:

$$
w_{3}=0.387 * 0.728+0.197 * 0.285+0.235 * 0.277=0.29
$$


The impact of popularity of eco-industrial knowledge on the sustainable development level is:

$$
w_{4}=0.094 * 0.428+0.115 * 0.285+0.136 * 0.277=0.11
$$

Among the four environmental practices of an EIP, the execution of environmental norms (43\%) plays the greatest role in achieving the sustainable development of EIPs in China. Guidance to key enterprises (29\%) has the second greatest effect on achieving sustainable development. Construction of industrial symbiosis is third (17\%), and popularity of eco-industrial knowledge is fourth (11\%).

\section{RESULTS AND DISCUSSION}

This paper used statistical analysis and analytic hierarchy process to identify the main factors of environmental practices that affect the sustainable development level of Chinese EIPs and to analyze the impact of different factors of environmental practices on the sustainable development level. The results are as follows.

First, the sustainable development of an EIP includes three factors: economic level, environmental level and social level. Economic level contributes the most to the sustainable development of an EIP, accounting for $42.8 \%$. The second largest contributor, environmental level, contributes $28.5 \%$. Social level contributes $27.7 \%$.

Second, the environmental practice of an EIP includes four factors: construction of industrial symbiosis, execution of environmental norms, guidance to key enterprises and popularity of ecoindustrial knowledge. The impact of these four factors on the three levels of sustainable development of an EIP was also analyzed and calculated in this article based on a regression analysis.

Third, using analytic hierarchy process, the impact of the four factors of environmental practice on sustainable development of an EIP was also analyzed. Execution of environmental norms has the greatest impact with a contribution rate of $43 \%$. Guidance to key enterprises has the second greatest impact, with a contribution rate of $29 \%$. Construction of industrial symbiosis is third, with a contribution rate of $17 \%$. Popularity of eco-industrial knowledge is fourth, with a contribution rate of $11 \%$.

To improve its sustainable development, an EIP in China first needs to issue specific environmental norms that are underpinned to its own characteristics under the frameworks of national and local requirement frameworks. For example, all of the enterprises in the EIP need to conduct cleaner production or energy auditing to ensure resource utility efficiency. An EIP also needs to consider identifying the key enterprises and providing them with guidance in environmental management and sustainable development, such as obtaining the certificate of environmental management system and trying to use renewable energy and resources. Industrial symbiosis, as a very important element in an EIP's sustainable development, is currently only the third contributor to the sustainable development of an EIP. That's possible because EIPs in China are in an early stage, and they are planning or just beginning to conduct industrial symbiosis. Therefore, the benefits from industrial symbiosis may be in the future. An EIP also needs to publicize knowledge on eco-industry and sustainable development by providing training or establishing clubs on waste minimization, for example. It is worth mentioning that EIPs in other countries may also face the same problems as those in China. Therefore, the results of this study might be worth of reference and application for governments and administration committees of EIPs.

\section{CONCLUSIONS}

The environmental practices of an EIP are critical to its sustainable development. This article first identifies three factors of sustainable development of an EIP: economic, environmental and social levels. Next, four types of environmental practices are identified using factor analysis; they are execution of environmental norms, guidance to key enterprises, construction of industrial symbiosis 
and popularity of eco-industrial knowledge. Among those four practices, execution of environmental norms plays the most important role in promoting the sustainable development of an EIP. Guidance to key enterprises plays the second most important role. Construction of industrial symbiosis is the third most important practice, and popularity of eco-industrial knowledge is the fourth. To achieve sustainable development, an EIP needs to conduct these four types of environmental practices. First, an EIP needs to establish its own specific environmental norms to guide enterprises under the frameworks of national and local environmental norms. Second, the administration committee of an EIP needs to identify those key enterprises and help them conduct eco-industry. For example, the administration committee can help key enterprises conduct cleaner production, circular economy, green supply chain management and other practices to drive these key enterprises to operate sustainably. Third, an EIP should analyze product and waste flows throughout the entire EIP so that opportunities for by-product exchange and industrial symbiosis can be identified. Fourth, the administration committee of an EIP also needs to educate the public about eco-industry and sustainable development. For example, relevant training can be provided periodically to the enterprises and communities.

By extending the theory of planned behavior, this article has developed a framework and statistical results that reveal environmental practices that are needed to improve an EIP's sustainable development level. However, there are some limitations to the current study and further studies are needed. First, considering the difficulties of collecting data, only four cities were chosen for conducting surveys. More cities need to be included to broaden this study. Second, the results show that four types of environmental practices affect the sustainable development level of an EIP and that their impact can be calculated. Further studies need to be conducted to reveal how these four types of environmental practices affect the sustainable development of an EIP.

\section{ACKNOWLEDGEMENTS}

This work was supported by grants from the National Natural Science Foundation of China Project (71473029, 71103024), the National Key Basic Research Program of China (2011CB013406) and the National Natural Science Foundation of China International (regional) Joint Research Project (71320107006).

\section{REFERENCES}

[1] Li, G.C., Zhou, J.M., Xu, S.X. \& Liu, R.Z., The present situation and countermeasure of Chinese ecological industrial park development. The Retrieval of the Agriculture in Taiwan, $\mathbf{3}$, pp. 23-26, 2009.

[2] He, P.Z., The exploration and thinking of modern ecological industrial park planning and construction. Sichuan Building Materials, 35(4), pp. 93-95, 2009.

[3] President's Council on Sustainable Development, Eco-industrial Park Workshop proceedings, President's Council on Sustainable Development, Washington, DC, 1996.

[4] Zhu, Q.H. \& Yang, Q.H., The empirical research of enterprises' environmental practice and its influencing factors in the construction of Chinese ecological industrial park. Management Review, 25(3), pp. 119-126, 2013.

[5] Geng, Y., Zhang, P., Cote, R. \& Fujita, T., Assessment of the national eco-industrial park standard for promoting industrial symbiosis in China. Journal of Industrial Ecology, 13(1), pp. 15-26, 2008. doi: http://dx.doi.org/10.1111/j.1530-9290.2008.00071.x

[6] Zhu, L., Zhou, J. \& Cui, Z., A method of controlling enterprises access to an eco-industrial park. Science of the Total Environment, 408(20), pp. 4817-4825, 2010. doi: http://dx.doi. org/10.1016/j.scitotenv.2010.06.035 
[7] Shang, H., The stability evaluation of eco-industrial parks. Science Research Management, 33(20), pp. 142-148, 2012.

[8] Wang, Z., Shi, L., Xu, Y. \& Hu, D., Analysis of Misuse of eco-industrial park concept in environmental policy in China. Environmental Science \& Technology, 32(11), pp. 195-200, 2009.

[9] WCED (World Commission on Environment and Development), Our Common Future (Brundtland Report), Oxford University Press: New York, NY, 1987.

[10] Moldan, B., Janouskova, S. \& Hak, T., How to understand and measure environmental sustainability: indicators and targets. Ecological Indicators, 17, pp. 4-13, 2012. doi: http:// dx.doi.org/10.1016/j.ecolind.2011.04.033

[11] UNSGHLPS, United Nations Secretary-General's High Level Panel on Global Sustainability Resilient People, Resilient Planet: a Future Worth Choosing, United Nations: New York, 2012.

[12] Lorek, S. \& Spangenberg, J.H., Sustainable consumption within a sustainable economy-beyond green growth and green economies. Journal of Cleaner Production, 63, pp. 33-44, 2014. doi: http://dx.doi.org/10.1016/j.jclepro.2013.08.045

[13] Li, H.D., Wang, S.Y. \& Zhao, D.T., Research on the ability of regional industrial sustainable development: from the perspective of "two-oriented" society. American Journal of Operation Research, 2, pp. 442-447, 2012. doi: http://dx.doi.org/10.4236/ajor.2012.23052

[14] Jiao, W.T. \& Boons, F., Toward a research agenda for policy intervention and facilitation to enhance industrial symbiosis based on a comprehensive literature review. Journal of Cleaner Production, 67, pp. 14-25, 2014. doi: http://dx.doi.org/10.1016/j.jclepro.2013.12.050

[15] Bonilla, S.H., Almeida, C.M.V.B., Giannetti, B.F. \& Huisingh, D., The roles of cleaner production in the sustainable development of modern societies: an introduction to this special issue. Journal of Cleaner Production, 18, pp. 1-5, 2010. doi: http://dx.doi.org/10.1016/j. jclepro.2009.09.001

[16] Li, W.Q. \& Chen, X., Overview of studies of the new industrialization theory. Shanghai Economic Review, 5, pp. 16-24, 2011.

[17] Ronchi, E., Federico, A. \& Musmeci, F., A system oriented integrated indicator for sustainable development in Italy. Ecological Indicators, 2, pp. 197-210, 2002. doi: http://dx.doi. org/10.1016/s1470-160x(02)00045-6

[18] Mu, H.F., Feng, X. \& Khim, H.C., Improved energy indices for the evaluation of industrial systems incorporating waste management. Ecological Engineering, 37, pp. 335-342, 2011. doi: http://dx.doi.org/10.1016/j.ecoleng.2010.11.026

[19] Quoc, C.N. \& Fei, Y., Study and evaluation on sustainable industrial development in the Mekong Delta of Vietnam. Journal of Cleaner Production, 86, pp. 389-402, 2015. doi: http:// dx.doi.org/10.1016/j.jclepro.2014.08.087

[20] Erkman, S., Industrial ecology: a historical view. Journal of Cleaner Production, 5(1-2), pp. 1-10, 1997. doi: http://dx.doi.org/10.1016/s0959-6526(97)00003-6

[21] O'Rourk, D., Connelly, L. \& Koshland, C., Industrial ecology: a critical review. International Journal of Environment and Pollution, 6(2-3), pp. 89-112, 1996.

[22] Heeres, R.R., Vermeulen,W.J.V. \&de Walle F.B., Eco-industrial park initiatives in the USA and the Netherlands: first lessons. Journal of Cleaner Production, 12(8-10), pp. 985-995, 2004. doi: http://dx.doi.org/10.1016/j.jclepro.2004.02.014

[23] Chertow, M., "Uncovering" industrial symbiosis. Journal of Industrial Ecology, 11(1), pp. 11-30, 2007. doi: http://dx.doi.org/10.1162/jiec.2007.1110

[24] Lombardi, R. \& Laybourn. P., Redefining industrial symbiosis: crossing academic-practitioner boundaries. Journal of Industrial Ecology, 16(1), pp. 28-37, 2012. doi: http://dx.doi. org/10.1111/j.1530-9290.2011.00444.x 
[25] Van Berkel, R., Quantifying sustainability benefits of industrial symbiosis. Journal of Industrial Ecology, 14(3), pp. 371-373, 2010. doi: http://dx.doi.org/10.1111/j.1530-9290.2010.00252.x

[26] Oh, D.S., Kim, K.B. \& Jeong, S.Y., Eco-industrial park design: a Daedeok Technovalley case study. Habitat International, 29(2), pp. 269-284, 2005. doi: http://dx.doi.org/10.1016/ j.habitatint.2003.09.006

[27] Boix, M., Montastruc, L., Azzaro-Pantel, C. \& Serge, D., Optimization methods applied to the design of eco-industrial parks: a literature review. Journal of Cleaner Production, 87, pp. 303-317, 2015. doi: http://dx.doi.org/10.1016/j.jclepro.2014.09.032

[28] Deutz, P. \& Gibbs, D., Industrial ecology and regional development: eco-industrial development as a cluster policy. Regional Studies, 42(10), pp. 1313-1328, 2008. doi: http://dx.doi. org/10.1080/00343400802195121

[29] Taddeo, R., Simboli, A. \& Morgante, A., Implementing eco-industrial parks in existing clusters. Findings from a historical Italian chemical site. Journal of Cleaner Production, 33, pp. 22-29, 2012. doi: http://dx.doi.org/10.1016/j.jclepro.2012.05.011

[30] Matarrita-Cascantea, D., Sene-Harpera, A. \& Stocks, G., International amenity migration: examining environmental behaviors and influences of amenity migrants and local residents in a rural community. Journal of Rural Studies, 38, pp. 1-11, 2015. doi: http://dx.doi.org/10.1016/j. jrurstud.2015.01.005

[31] Meng, Q.F., Li, Z. \& Sheng, Z.H., The research situation and development trend enterprise environment practice affecting factors. Chinese Population, Resources and Environment, 20(9), pp. 100-106, 2010.

[32] Wang, H., Zhen, X.M. \& Liu, F., The study of high and new technology industrial park ecological industrial park planning. Ecological Economy, 2, pp. 177-181, 2007.

[33] Boons, F.A.A. \& Baas, L.W., Types of industrial ecology: the problem of coordination. Journal of Cleaner Production, 5(1-2), pp. 79-86, 1997. doi: http://dx.doi.org/10.1016/s09596526(97)00007-3

[34] Raymond, P. \& Cote, T.S., Supporting pillars for industrial ecosystems. Journal of Cleaner Production, 5(1-2), pp. 67-74, 1997. doi: http://dx.doi.org/10.1016/s0959-6526(97)00016-4

[35] Brian, H.R., The application of industrial ecology principles and planning guidelines for the development of eco-industrial parks: an Australian case study. Journal of Cleaner Production, 12, pp. 997-1010, 2004. doi: http://dx.doi.org/10.1016/j.jclepro.2004.02.037

[36] Zhang, L., Yuan, Z. \& Bi, J., Eco-industrial parks: national pilot practices in China. Journal of Cleaner Production, 18, pp. 504-509, 2010. doi: http://dx.doi.org/10.1016/j. jclepro.2009.11.018

[37] Yong, G. \& Raymond, C., Environmental management systems at the industrial park level in China. Environmental Management, 31(6), pp. 784-794, 2003. doi: http://dx.doi.org/10.1007/ s00267-002-2854-9

[38] Geng, Y., Zhang, P. \& Sergio, U., Emerge analysis of an industrial park: the case of Dalian, China. Science of the Total Environment, 408, pp. 5273-5283, 2010. doi: http://dx.doi. org/10.1016/j.scitotenv.2010.07.081

[39] Xiang, M. \& Liu, F., Different subjects' behavior way in the development of circular economy. Environmental Protection, 1, pp. 54-60, 2005.

[40] Li, Y.Y., The construction ways and management methods of industrial ecological system. Ecological Environment, 17(4), pp. 1701-1714, 2008.

[41] Zilahy, G., Organizational factors determining the implementation of cleaner production measure in the corporate sector. Journal of Cleaner Production, 12, pp. 11-319, 2004. doi: http:// dx.doi.org/10.1016/s0959-6526(03)00016-7 
[42] Chao, J., Ma, S.J. \& Huang, Y.Z., The landscape construction of modern industrial park dominated by the Industry behavior. Ecological Economy, 5, pp. 128-131, 2012.

[43] Pierre, D., Cities and industrial symbiosis. Journal of Industrial Ecology, 5(4), pp. 29-44, 2002. doi: http://dx.doi.org/10.1162/10881980160084024

[44] Deng, H., The study of Chinese industry ecosystem stability influence factors, Dalian University of Technology Press: Dalian, 2006.

[45] Qu, Y., Liu, Y., Nayak, R.R. \& Li, M., Sustainable development of eco-industrial parks in China: effects of managers' environmental awareness on the relationships between practice and performance. Journal of Cleaner Production, 87, pp. 328-338, 2015. doi: http://dx.doi. org/10.1016/j.jclepro.2014.09.015

[46] Zhang, S.Q., The exploration of sustainable development environment index system. World Environment, 3, pp. 8-9, 1996.

[47] Chen, K., SPSS Statistical Analysis from the Entry to the Master, Tsinghua University Press: Beijing, 2010.

[48] Klaus, B., Bernd, E., Wulff, P., Wang, X. \& Rolf, W., Multivariate statistical analysis, Gezhi Press and Shanghai People's Publishing Press: Shanghai, 2008.

[49] Yu, J. \& He, X., Statistical Analysis and Application, Beijing People's Posts and Telecommunications Press: Beijing, 2003.

[50] Nunnally, J.C. \& Berstein, I.H., Psychometric Theory, McGraw-Hall: New York, 1994.

[51] Qiu, H.Z., Quantitative Research and Statistical Analysis, Chongqing University Press: Chongqing, 2009. 